\title{
British Indian Ocean Territory
}

National Cancer Institute

\section{Source}

National Cancer Institute. British Indian Ocean Territory. NCI Thesaurus. Code C16365.

An archipelago in the Indian Ocean, south of Africa, about one-half the way from Africa to Indonesia and south of the Maldives. 